\title{
Metode Penilaian untuk Perilaku Profesional: The Professionalism Mini-Evaluation Exercise (P-MEX) sebuah Alternatif?
}

\author{
Yoga Pamungkas Susani \\ Fakultas Kedokteran Universitas Mataram \\ Mataram
}

\begin{abstract}
Background: Due to higher attention on professionalism of doctor, greater concern in medical education should be placed on the development of the qualities of professional behavior. Assessment of professional behavior for medical students becomes very essential. However, there is still confusion in selecting and implementing assessment methods

Objective: To provide an overview of professional behavior assessment and considerations in implementing assessment method especially P-MEX.

Discussion: P-MEX was discussed using the framework of 7 criteria for good assessment, related to the validity, consistency, equivalence, feasibility, educational effect, catalytic effect and acceptability. Professionalism is multidimensional and one method of assessment cannot give reliable representation of students' behavior, for that reasons combination of assessment tools is required. The assessment must valid and reliable also. Many methods for assessing professional behavior have been developed, one of them is the Professionalism Mini-Evaluation Exercise (P-MEX), which format is based on Mini-Clinical Encounter Exercise (mini-CEX). This article will describe the outline about professional behavior definition, methods of assessment especially P-MEX, whether P-MEX is a good alternative for assessing professional behavior.

Conclusion: P-MEX can be considered as one of assessment method to be applied in assessing student's professional behavior. However, adapting the instrument to be ready to use here requires a process that can maintain the validity and reliability would be better if the instrument is tailored to Indonesian context.
\end{abstract}

Keywords: professionalism, professional behavior, assessment, P-MEX, mini-CEX

\begin{abstract}
Abstrak
Latar Belakang: Tingginya perhatian masyarakat terhadap profesionalisme dokter menjadikan pendidikan kedokteran perlu menekankan perkembangan kualitas perilaku profesional mahasiswa. Penilaian terhadap perilaku profesional mahasiswa kedokteran menjadi hal yang esensial. Namun demikian, masih ada kebingungan dalam memilih dan menerapkan suatu metode penilaian.

Tujuan: untuk memberikan gambaran penilaian perilaku profesional dan pertimbangan dalam melaksanakan metode penilaian terutama P-MEX.

Pembahasan: P-MEX dibahas dengan kerangka 7 kriteria penilaian yang baik, yaitu terkait validitas, konsistensi, ekuivalensi, kelayakan, efek pendidikan, efek katalitik dan akseptabilitas. Profesionalisme bersifat multidimensi, satu metode penilaian saja tidak cukup untuk merepresentasikan perilaku profesional. Diperlukan kombinasi beberapa metode dengan penilaian yang handal dan terpercaya. Salah satu metode yang telah dikembangkan adalah observasi menggunakan format Professionalism Mini-Evaluation Exercise (P-MEX). P-MEX dikembangkan berdasar format Mini-Clinical Encounter Exercise (Mini CEX). Artikel ini akan membahas gambaran tentang perilaku profesional dan metode penilaiannya terutama ulasan tentang P-MEX sebagai salah satu alternatif.
\end{abstract}

Korespondensi: yoga_pamungkas_s@yahoo.com 
Kesimpulan: P-MEX dapat menjadi salah satu metode penilaian untuk dapat diterapkan dalam menilai perilaku profesional mahasiswa. Namun, mengadaptasi instrumen untuk siap digunakan di Indonesia memerlukan proses agar validitas dan reliabilitasnya terjaga. Akan lebih baik apabila instrumen tersebut disesuaikan dengan konteks di Indonesia.

Kata Kunci: profesionalisme, perilaku profesional, P-MEX, mini-CEX

\section{PENDAHULUAN}

Profesionalisme menjadi tuntutan bagi seorang dokter dalam memberikan pelayanan dan menjalankan perannya. Dokter tidak lagi dituntut untuk sekedar "mengobati penyakit" namun lebih pada pelayanan holistik kepada pasien. Dokter harus memiliki kemampuan komunikasi yang baik dan mampu membangun hubungan dokter-pasien yang baik. Tidak hanya pelayanan kepada pasien, namun dokter juga dituntut untuk dapat bekerja sama dengan profesi lain, bahkan berlaku sebagai pemimpin dalam komunitas ataupun manajer. ${ }^{1}$

Pembelajaran profesionalisme merupakan hal yang esensial dalam pendidikan kedokteran. Namun demikian, penyelenggaraan pendidikan kedokteran seringkali masih lebih banyak terfokus pada pengembangan aspek knowledge dan skills mahasiswa, sehingga usaha pengembangan profesionalisme hingga penilaiannya masih terabaikan. Kenny ${ }^{2}$ menyatakan bahwa pendidikan dokter kurang memperhatikan pembentukan nilai dan attitude yang terjadi dalam pembentukan dokter baru. Diharapkan dengan banyaknya kepedulian terhadap profesionalisme dokter, penyelenggaraan pendidikan tidak hanya mementingkan aspek knowledge dan skills namun juga perilaku profesional.

\section{TUJUAN}

Artikel ini akan memberikan deskripsi secara umum tentang profesionalisme, metode-metode yang dapat digunakan untuk menilai perilaku profesional, dan penjelasan lebih dalam tentang P-MEX sebagai salah satu metode yang dikembangkan untuk penilaian perilaku profesional.

\section{PEMBAHASAN}

\section{Tinjauan Umum Tentang Profesionalisme}

Secara universal, 30 tahun yang lalu, professionalisme dalam pendidikan kedokteran belum banyak dikembangkan. ${ }^{3}$ Tidak ada konsep profesi dan profesionalisme, hanya ada beberapa konsep behaviour yang seringkali menjadi hal yang tidak mendapatkan perhatian dibanding aspek kognitif. ${ }^{3}$ Saat ini konsep profesionalisme dalam pendidikan kedokteran telah banyak mendapatkan perhatian dan terjabarkan dalam elemenelemen yang spesifik.

Menurut Cruess \& Cruess ${ }^{4}$, profesi merupakan suatu pekerjaan yang elemen intinya didasarkan pada penguasaan pengetahuan dan keterampilan yang kompleks yang ditujukan untuk pelayanan publik dengan kode etik dalam menjalankannya. Selain itu, dalam profesionalisme terkandung unsur komitmen untuk senantiasa kompeten, memiliki integritas, moral, altruisme untuk publik yang membentuk dasar kontrak sosial antara profesi dengan masyarakat. Profesi memiliki hak untuk menggunakan pengetahuan, otonomi dalam praktek, self-regulation, serta akuntabel kepada yang dilayani, kepada profesi dan kepada sosial masyarakat. ${ }^{4}$

Profesionalisme merupakan hal kompleks yang memiliki definisi dan penjabaran atribut yang berbeda-beda antara penyelenggara pendidikan satu dan lainnya. Wilkinson et al. mengelompokkan profesionalisme ke dalam 5 atribut, yaitu: ketaatan terhadap prinsip etika (adherence to ethical practice principles), interaksi efektif dengan pasien dan pihak lain yang penting terhadap pasien (effective interactions with patients and with people who are important to those patients), interaksi efektif dengan orang lain yang bekerja dalam sistem kesehatan (effective interactions with people working within the health system), reliabilitas (reliability), 
dan komitmen terhadap pemeliharaan otonomi dan perkembangan kompetensi yang berkelanjutan (commitment to autonomous maintenance/ improvement of competence in one self, others, and systems $)^{5}$

Atribut-atribut profesionalisme masih berupa konsep abstrak yang sulit untuk dinilai. Langkah yang dilakukan adalah mengkonkritkan konsep tersebut menjadi indikator-indikator perilaku yang dapat diamati. Namun demikian, penilaian ini baru berupa penilaian perilaku profesional, belum menilai profesionalisme sebagai suatu sifat ataupun karakter. Sebagai contoh penjabaran terhadap perilaku profesional menurut Universitas Maastricht merupakan perilaku atau behaviour yang menunjukkan sifat profesional yang dapat diamati atau diobservasi meliputi 3 aspek, yaitu dealing with tasks, dealing with others, dealing with oneself. ${ }^{6}$ P-MEX sendiri merupakan suatu alat untuk memandu pendidik dalam melakukan penilaian perilaku profesional.

\section{Mengapa Penilaian Terhadap Profesionalisme Penting?}

"Assessment drives learning", penilaian yang baik akan memberikan efek bagi pendidikan atau pembelajaran mahasiswa. Mahasiswa sangat peduli dengan hal-hal yang dinilai dari diri mereka. Penilaian juga memotivasi mahasiswa untuk belajar hal yang penting. Diharapkan mahasiswa menjadi lebih mengenal perilaku yang profesional ataupun yang tidak serta terbiasa untuk berperilaku profesional. Akibat selanjutnya adalah internalisasi kebiasaan tersebut sehingga menjadi karakter. Dengan demikian, penilaian juga merupakan proses pembelajaran.

Menurut Stern ${ }^{7}$, untuk dapat membentuk profesionalisme, dalam kurikulum pendidikan perlu ada tujuan belajar yang jelas (expectations), tersedia program yang memberikan pengalaman kepada mahasiswa (experiences), serta evaluasi terhadap luaran atau sistem penilaian yang jelas (evaluations). Dalam proses pendidikan, penilaian profesionalisme yang akurat memiliki beberapa manfaat, yaitu: ${ }^{7}$

1. Mendeteksi mahasiswa yang memiliki perilaku ekstrim, dan sebaliknya yang memiliki perilaku profesional.
2. Menyediakan umpan balik bagi mahasiswa dalam kontinum pendidikannya.

3. Menilai ada tidaknya perubahan profesionalisme sebagai hasil dari suatu intervensi pendidikan.

Melihat manfaat yang begitu besar, tentu saja institusi pendidikan kedokteran perlu memikirkan sistem penilaian profesionalisme bagi mahasiswanya. Namun demikian, banyak tantangan dan kesulitan dalam penilaian profesionalisme. Seringkali observasi dalam penilaian profesionalisme terjadi pada saat mahasiswa dalam perilaku terbaiknya ${ }^{7}$, misal: di ruang konferensi, tutorial, atau kuliah. Mahasiswa bisa saja berperilaku baik ketika dinilai, karena mereka sadar bahwa mereka dinilai. Sangat sedikit kesempatan untuk menilai dalam seting realistik. Solusi dari permasalahan ini adalah menambah jumlah observasi, variasi observer dan variasi seting. ${ }^{7}$ Permasalahan lain dalam penilaian profesionalisme adalah dalam menjelaskan butir-butir dalam observasi tersebut. ${ }^{?}$

Penilaian profesionalisme juga rentan terhadap terjadinya generalisasi yang berlebihan. ${ }^{7}$ Seringkali terjadi kecenderungan dosen berasumsi bahwa seseorang yang berperilaku buruk pada satu situasi, dia akan berperilaku buruk untuk segala situasi. Seseorang belum tentu berperilaku identik bahkan dalam situasi yang identik, sehingga permasalahan lain dalam penilaian profesionalisme adalah menentukan representatif tidaknya hasil observasi yang dilakukan. Penilaian profesionalisme perlu memperhatikan konteks terjadinya perilaku tersebut. ${ }^{7}$

\section{Metode Assessment terhadap Perilaku Profesional}

Penilaian professionalisme yang valid dan reliabel menjadi tuntutan ketika kita mengharapkan lulusan dokter dapat berperilaku profesional. Penilaian yang bertujuan untuk formatif sangat penting untuk mendukung perkembangan profesionalisme mahasiswa. Hal ini disebabkan, dengan penilaian formatif, mahasiswa mendapatkan banyak umpan balik untuk dapat memperbaiki perilakunya.

Hingga saat ini metode penilaian perilaku profesional yang komprehensif memang belum ada, namun beberapa metode telah dikembangkan dan dapat diterapkan pada seting yang berbeda (Tabel 1). Penilaian 
profesionalisme akan lebih efektif dan reliabel dengan penerapan metode yang bervariasi, penilaian yang berulang-ulang, penilai independen yang berbeda-beda dan dalam kurun waktu yang cukup lama. ${ }^{1-7}$ Selain itu perlu didasarkan pada seting, situasi dan kondisi yang berbeda-beda. ${ }^{5}$

Tabel 1. Metode penilaian terhadap profesionalisme ${ }^{5}$

\begin{tabular}{|c|c|}
\hline Kelompok metode & Contoh \\
\hline $\begin{array}{l}\text { Penilaian dengan observasi saat } \\
\text { dinical encounter }\end{array}$ & $\begin{array}{l}\text { - Mini-Clinical Evaluation Exercise (mini-CEX) } \\
\text { - Professionalism Mini-Eqaluation Exercise (P-MEX) } \\
\text { - Ophthalmic clinical evaluation exercise } \\
\text { - Standardized Direct Observation assessment Tool }\end{array}$ \\
\hline Pandangan dari pihak la in & - Multisource feedback \\
\hline $\begin{array}{l}\text { Catatan tentang insiden perilaku } \\
\text { tidak profesional }\end{array}$ & - Incident reporting form \\
\hline Simulasi & $\begin{array}{l}\text { - Ethical dilemmas in high-fidelity patient simulations } \\
\text { - OSCE }\end{array}$ \\
\hline Paper based test & $\begin{array}{l}\text { - Defining issues test } \\
\text { - Objective Structured Video Examinations } \\
\text { - Critical incident report } \\
\text { - Multiple-shoice test }\end{array}$ \\
\hline Pendapat pasien & $\begin{array}{l}\text { - FACE cards } \\
\text { - Wake Forest Physician Trust Scheme } \\
\text { - Patient assessment questionnaire (PAQ) } \\
\text { - Simulated patient rating scales } \\
\text { - Humanism scalc } \\
\text { - Royal College of Physicians Patient Questionnaire }\end{array}$ \\
\hline Pandangan global dari supervisor & $\begin{array}{l}\text { - Global rating form } \\
\text { - University of Michigan Department of Surgery } \\
\text { Professionalism Assessment Instrument } \\
\text { - Evaluation of professional behaviour in general practice (EPROGP) } \\
\text { - Amsterdam attitudes and communication scale }\end{array}$ \\
\hline Self administered rating scale & $\begin{array}{l}\text { - Time Management Inquiry Form } \\
\text { - Pharmacy Professionalism Instrument } \\
\text { - Groningen Reflection Ability Scale } \\
\text { - Cross-cultural adaptability inventory } \\
\text { - Cultural competence self-assessment questionnaire } \\
\text { - Interpersonal Reactivity Index } \\
\text { - Penn State College of Medicine Professionalism } \\
\text { Questionnaire }\end{array}$ \\
\hline Penggunaan kuesioner ( tool use) & $\begin{array}{l}\text { - Cultural competence self-assessment questionnaire } \\
\text { - Interpersonal Reactivity Index } \\
\text { - Penn State College of Medicine Professionalism Questionnaire }\end{array}$ \\
\hline Critical incident report & Critical incident report \\
\hline
\end{tabular}

Masing-masing jenis metode (Tabel 1) tidak mampu secara sempurna menilai keseluruhan aspek atau atribut profesionalisme. Penilaian dengan observasi langsung saat clinical encounter, dalam hal ini mini-CEX dan modifikasinya P-MEX merupakan metode yang baik dan mampu menilai banyak aspek terutama dalam hal interaksi, baik kepada pasien maupun orang lain dan juga pada penerapan prinsip etika. ${ }^{5}$ Namun demikian, sesuai dengan permasalahan dalam penilaian profesionalisme di atas, perilaku yang diperlihatkan 
mahasiswa belum tentu mencerminkan perilaku yang sesungguhnya. Hal ini terjadi karena mahasiswa mengetahui bahwa dirinya sedang diobservasi. Oleh karenanya, pandangan dari teman, kolega atau pasien dapat menjadi informasi komplementer. ${ }^{5}$ Alasan moral suatu perilaku dapat dinilai dengan simulasi saat OSCE, atau penilaian secara tertulis. Hal yang masih belum dapat dinilai dari kesembilan metode di atas adalah kemampuan refleksi dan self-assessment, belajar sepanjang hayat, menangani ketidakpastian, keseimbangan memperhatikan kepentingan orang lain dengan tetap memperhatikan atau merawat diri sendiri, mencari dan merespon hasil audit, dan pengembangan pengetahuan. ${ }^{5}$

\section{Professionalism Mini-Evaluation Exercise (P-MEX)}

Professionalism Mini-Evaluation Exercise (P-MEX) dikembangkan di Canada oleh McGill University dan University of Toronto. ${ }^{8}$ Format P-MEX dikembangkan berdasarkan format Mini-CEX yang lebih dahulu dikenal dalam menilai kempetensi klinik. Format mini-CEX mudah digunakan, memungkinkan adanya feedback, serta memiliki validitas dan reliabilitas yang baik. ${ }^{9} \mathrm{Hal}$ ini mendorong pengembangan P-MEX berdasarkan format mini-CEX. Meskipun dalam mini-CEX sudah terdapat komponen professionalism sebagai salah satu kategori penilaian, namun mini-CEX tidak mengidentifikasi behavior secara lebih spesifik dalam konteks nyata. P-MEX didesain untuk dapat diterapkan dalam observasi selama 15-20 menit selama aktivitas mahasiswa. ${ }^{8}$

P-MEX terdiri atas 24 butir pernyataan yang terbagi dalam 4 kategori, yaitu: hubungan dokter-pasien (doctor-patient relationship skills) terdiri atas 7 butir antara lain: mendengarkan aktif dalam komunikasi dengan pasien, menunjukkan sikap menghormati pasien, dan lain-lain; keterampilan refleksi (reflective skills) terdiri atas 5 butir antara lain: menyadari keterbatasan, menerima umpan balik, dan lain-lain; keterampilan manajemen waktu (time management skills) terdiri atas 3 butir antara lain: tepat waktu, mengerjakan tugas dengan baik, dan lain-lain; dan keterampilan membangun hubungan interprofesional (interprofessional relationship skills) terdiri atas 9 butir antara lain menunjukkan sikap hormat terhadap kolega, menghindari bahasa yang bersifat ejekan, dan lain-lain. Kategori penilaian terdiri atas 4 poin skala, yaitu:
$4=$ exceeded expectations, $3=$ met expectations, $2=$ below expectations, dan $1=$ unacceptable. Format P-MEX ini disusun untuk dapat digunakan dalam situasi dengan ataupun tanpa pasien, oleh karenanya diberikan kategori penilaian kelima yaitu "not observed" (tidak diobservasi) atau "not applicable" tidak dapat diterapkan.

P-MEX didesain untuk dapat digunakan dalam berbagai situasi yang memungkinkan perilaku mahasiswa dapat diobservasi, termasuk dalam hal ini proses menghadapi pasien ataupun proses diskusi dalam kelompok. Evaluasi didasarkan pada interaksi yang relatif singkat dan terjadi berulang kali sebagai bagian dari proses pendidikan, dengan demikian setiap mahasiswa dapat dievaluasi dalam beberapa kesempatan dengan penilai yang berbeda-beda. ${ }^{8}$ Seperti halnya pada mini-CEX, penilaian P-MEX tidak diharuskan meliputi semua hal, misalnya: penilaian boleh hanya berfokus pada keterampilan menjalin hubungan antara dokter dengan pasien saja, atau komponen yang lain.

Norcini et al. ${ }^{10}$ memaparkan 7 kriteria penilaian secara umum (bukan hanya untuk penilaian profesionalisme) yang baik. Kriteria tersebut meliputi aspek validitas, konsistensi, ekuivalensi, kelayakan, efek pendidikan, efek katalitik, dan akseptabilitas. Berikut P-MEX dibahas berdasar 7 kriteria tersebut:

1. Validitas

Penilaian yang valid mengukur hal-hal sesuai dengan yang ingin diukur. Pengembangan P-MEX diawali dari 142 perilaku profesional yang diidentifikasi oleh 92 orang staf dosen di McGill University dan residen dalam sebuah workshop. Sebelumnya seluruh peserta diberikan definisi tentang profesi, definisi penyembuh, dan atributatribut profesi dan penyembuh yang digunakan dalam pembelajaran di McGill. Selanjutnya, mereka mengidentifikasi perilaku yang sesuai dengan definisi dan atribut tersebut. Selanjutnya 142 butir tersebut dianalisis dan ditriangulasi dengan hasil workshop lain di Amerika Utara dan hasilnya serupa. Analisis menghasilkan 24 butir instrumen. Instrumen tersebut diujicobakan dalam skala kecil untuk mendapatkan umpan balik. Selanjutnya, instrumen yang telah direvisi diuji coba kembali dan menghasilkan 211 hasil P-MEX dalam berbagai seting, untuk kemudian 
dianalisis menggunakan analisis faktor. Hasil analisis faktor menunjukkan validitas konstruk yang baik dari 4 kategori dalam P-MEX. ${ }^{8}$ Jika melihat proses pengembangan instrumen, maka validitas isi P-MEX cukup baik dalam menilai perilaku profesional.

Jika dicermati kembali, beberapa butir penilaian tampaknya sulit untuk diobservasi dan dinilai hanya dalam waktu 15-20 menit interaksi saja. Misalnya pada butir menjaga keterahasiaan pasien, menggunakan sumber daya dengan tepat, meyakinkan kesinambungan perawatan pasien. Indikator-indikator penilaian seperti apa yang dapat digunakan untuk mengukur butir-butir tersebut juga perlu disesuaikan dengan konteks. Selain itu, ada butir yang sulit dinilai hanya dengan observasi. Seperti menempatkan dan mengarahkan gap pengetahuan dan keterampilannya, menyadari kesalahan dan kekurangannya (pada komponen keterampilan refleksi), butirbutir tersebut sulit untuk dinilai hanya dengan observasi.

2. Konsistensi

Hasil penilaian sebaiknya sama, jika diulang dalam kondisi serupa. Dengan sekali pengukuran terhadap 1 mahasiswa, koefisien generabilitas yang dihasilkan adalah 0,28. Delapan kali pengukuran atau observasi meningkatkan koefisien tersebut menjadi 0,76 dengan interval kepercayaan yang cukup sempit (SEM 0,11, 95\% CI 3,03-3,47) ${ }^{8}$. Untuk mendapatkan reliabilitas dengan koefisien 0,8 dibutuhkan 10-12 kali observasi atau pengukuran. ${ }^{8}$ Studi di Jepang oleh Tsugawa et al menunjukkan validitas dan reliabilitas yang tidak jauh berbeda dengan studi Cruess et al. Tsugawa et al. menambahkan beberapa butir penilaian yang disesuaikan dengan karakter kontekstual Jepang. ${ }^{11}$ Dengan P-MEX yang telah dimodifikasi ini, dibutuhkan 14-16 kali observasi atau pengukuran untuk mendapatkan reliabilitas dengan koefisien $0,8{ }^{11}$

3. Ekuivalensi

Penilaian yang sama menghasilkan nilai atau keputusan setara bila dilakukan di institusi atau siklus pengujian yang berbeda. Seperti halnya sistem penilaian pada umumnya, penilai perlu memahami terlebih dahulu butir-butir yang dinilai. P-MEX terdiri atas 24 butir penilaian yang memerlukan penjelasan tentang setiap butir penilaian. Hal ini penting untuk memberikan gambaran dan menyamakan persepsi penilai terhadap butir tersebut. Perbedaan persepsi tentang butir penilaian akan sangat berpengaruh terhadap hasil penilaian itu sendiri.

4. Kelayakan (feasibility)

P-MEX didesain untuk dapat diterapkan dengan observasi 15-20 menit sesi pembelajaran. Seperti mini-CEX, P-MEX juga dapat diterapkan dalam berbagai seting. P-MEX juga menyediakan pilihan not observable/ not applicable untuk butir-butir tertentu yang mungkin tidak sesuai dengan seting penilaian ataupun tidak dapat dinilai hanya dengan waktu 15-20 menit. Namun demikian, dalam pelaksanaannya, jika dibandingkan dengan mini-CEX yang hanya menilai 7 hal, tentu saja berbeda dengan P-MEX yang menilai 24 butir. Penilai dalam P-MEX akan memerlukan waktu yang lebih lama untuk melengkapi lembar penilaian P-MEX. Perlu dipikirkan pula tentang beban penilai untuk menilai hal lain (misal miniCEX) selain P-MEX dalam sekali observasi terutama di klinik. P-MEX belum tereksplorasi dalam hal praktikabilitas dan kemudahan penilai dalam menggunakannya.

5. Efek pendidikan

Penilaian memberikan motivasi kepada mahasiswa untuk mempersiapkan diri sebaikbaiknya sehingga mendapat manfaat pendidikan. Dengan adanya butir-butir indikator perilaku yang ada dalam P-MEX diharapkan mahasiswa lebih memahami perilaku yang diharapkan untuk menjadi seorang dokter profesional dan mencoba untuk menerapkannya dalam kehidupan seharihari.

6. Efek katalitik

Penilaian memberikan hasil dan umpan balik yang menciptakan, menyempurnakan, dan menunjang pendidikan ke depannya. Efek katalitik akan didapatkan jika penilaian melekat dengan pembelajaran, menyediakan umpan balik yang spesifik, berkelanjutan atau terus menerus, dan tepat waktu. Seperti halnya pada mini-CEX, P-MEX memungkinkan adanya feedback dan diskusi sesaat untuk memperkuat penilaian. 
Cruess et al juga menekankan bahwa penilaian dengan P-MEX merupakan penilaian yang didasarkan pada observasi dalam konteks yang bisa berbeda-beda. Penilaian yang dilakukan juga harus disesuaikan dengan konteksnya. Misalnya: perilaku terlambat dapat dinilai berbeda-beda sesuai konteksnya. Jika mahasiswa terlambat karena baru saja selesai membantu penanganan pasien gawat, maka perilaku terlambat dapat dimaklumi (acceptable), namun jika terlambat akibat kelalaian maka perilaku tersebut menjadi tidak dapat diterima. Selain itu, berbeda dengan mini-CEX yang menilai profesionalisme secara global, P-MEX dapat menilai profesionalisme dengan lebih spesifik pada komponennya. Diharapkan umpan balik yang diterima oleh mahasiswa juga lebih spesifik untuk memperbaiki perilaku profesional mereka.

7. Akseptabilitas

Proses maupun hasil penilaian kredibel sehingga dapat diterima oleh para stakeholder. Karena sifatnya yang melekat dalam proses pembelajaran, P-MEX tidak memerlukan biaya besar seperti OSCE atau simulasi yang lain. Hanya saja kemudahan dari penilai juga perlu dipertimbangkan. Dari segi hasil penilaian, jika melihat validitas dan reliabilitasnya maka P-MEX cukup dapat memberikan hasil yang bisa diterima, jika dilakukan secara benar.

\section{Tantangan dan Rekomendasi}

1. Terkait validitas, butir-butir instrumen perlu ditinjau kembali. Dalam profesionalisme terdapat unsur negosiasi ataupun kontrak sosial antara dokter sebagai pihak yang melayani dengan masyarakat sebagai pihak yang dilayani. Profesionalisme bersifat dinamis terkait waktu maupun sosio-kultural masyarakat. ${ }^{4}$ P-MEX dikembangkan di Amerika, sehingga ada kemungkinan perbedaan indikator perilaku profesional dengan di Indonesia. Meskipun atribut-atribut profesionalisme bersifat universal, namun ada penekanan-penekanan pada aspek tertentu. Studi menyebutkan dokter di Asia diharapkan lebih altruis, percaya diri, memperhatikan nilai dalam seting tempat kerja, dan mampu beradaptasi dalam seting tempat kerja yang berbeda. ${ }^{12}$ Jika Tsugawa et al. membuat modifikasi penilaian sesuai dengan kondisi di Jepang ${ }^{11}$, tantangan bagi peneliti di bidang pendidikan kedokteran untuk menilai kesesuaian instrumen dengan harapan masyarakat Indonesia tentang perilaku profesional dokter dan atau menambahkan butir instrumen.

2. Studi tentang penggunaan P-MEX masih terbatas, sehingga masih terbatas pula penjelasan tentang konsistensi, ekuivalensi, kelayakan, efek pendidikan, efek katalitik dan akseptabilitas dalam penerapan P-MEX. Sangat terbuka bagi peneliti dan pendidik di Fakultas Kedokteran di Indonesia untuk menerapkan dan mengevaluasi penerapannya dalam bentuk penelitian. Dengan demikian, hasil penelitian tersebut dapat menjadi "evidence" untuk penerapan lebih lanjut.

3. Penilaian profesionalisme dengan observasi saja tidak dapat mengukur sifat atau karakter profesional. Yang dapat diukur dengan observasi adalah perilaku yang tampak saja. Dengan demikian, risiko untuk adanya perilaku palsu saat penilaian dilakukan sangat dimungkinkan. Penilaian yang berulang-ulang diharapkan dapat menunjukkan perilaku sebenarnya dari mahasiswa tersebut. Triangulasi dengan metode penilaian lain, penilai jamak, dengan konteks ataupun kompleksitas yang berbeda sangat dianjurkan.

4. P-MEX hanya metode, namun proses selanjutnya terhadap hasil tersebut bergantung lagi ke sistem penilaian umum yang diterapkan oleh institusi kepada mahasiswa. Apakah hasil P-MEX berperan sebagai penilaian formatif atau sumatif, bagaimana dengan tindak lanjut atau "treatment" bagi mahasiswa dengan hasil penilaian rendah ataupun adanya insiden-insiden penyimpangan profesionalisme sebaiknya diatur tersendiri di luar P-MEX.

5. Terkait dengan rekomendasi Konferensi Ottawa tahun 2010 tentang rekomendasi terhadap penilaian profesionalisme ${ }^{13}$, P-MEX adalah salah satu instrumen yang berbasis pada pemahaman bahwa profesionalisme adalah proses individual dalam konstruksi karakter, sifat, perilaku ataupun kognitif. Sehingga dampaknya lebih ke individu mahasiswa. Ada lingkup pemahaman lain selain individual, yaitu profesionalisme sebagai 
fenomena yang dibangun interpersonal, dan profesionalisme sebagai fenomena yang dibangun oleh institusional atau sosietal. Pemahaman yang lebih luas membawa dampak yang lebih luas bukan hanya pada pembentukan perilaku profesional mahasiswa, namun hingga pembentukan lingkungan pendidikan yang profesional maupun lebih luas lagi ke institusi maupun sistem yang lebih tinggi. Penilaian yang melibatkan karakter yang menjadi harapan masyarakat ataupun kebutuhan stakeholder dalam bidang kesehatan akan menjadi lebih penting.

\section{KESIMPULAN}

Penilaian profesionalisme yang valid dan reliabel menjadi tuntutan ketika kita mengharapkan lulusan dokter dapat berperilaku profesional. P-MEX dapat menjadi alternatif untuk dapat digunakan sebagai salah satu metode dalam penilaian maupun pengembangan perilaku profesional mahasiswa kedokteran. Pengembangan dan penelitian lebih lanjut terhadap penerapan instrumen ini di Indonesia masih perlu dilakukan.

\section{DAFTAR PUSTAKA}

1. Boelen C. The five-star doctor: an asset to health care reform? [document on the internet]. World Health Organization, Geneva, Switzerland [cited 2009 Oct 23]. Available from: http://www.who.int/hrh/en/ HRDJ_1_1_02.pdf

2. Kenny N. Searching for doctor good: virtues for the twenty-first century. In: Kenny N, Shelton W, editors. Advances in bioethics. Lost virtue: professional character development of medical education, volume 10. Amsterdam: Elsevier Ltd; 2006.

3. Arnold L. Assessing professional behaviour: yesterday, today, and tomorrow. Academic Medicine. 2002; 77(6): 502-15.
4. Cruess SR, Cruess RL. The cognitive base of professionalism. In: Cruess RL, Cruess SR \& Steinert Y, editors. Teaching medical professionalism. New York: Cambridge University Press; 2009.

5. Wilkinson TJ, Wade WB, Knock LD. A Blueprint to assess professionalism: results of a systematic review. Academic Medicine. 2009; 84(5):551-8.

6. Professional behavior, teaching, assessing and coaching students. In: Van Luijk SJ, editor. Final report. Project Team Consilium Abeundi appointed by the NL Council of Medical Deans of the Dutch Federation of University Medical Centers. Maastricht: Universitaire Pers Maastricht; 2005.

7. Stern DT. A framework for measuring professional-ism. In: Stern DT, editor. Measuring medical professionalism. New York: Oxford University Press; 2006.

8. Cruess R, Mcllroy H, Cruess S, Ginsburg S, Steinert Y. The professionalism mini-evaluation exercise: a preliminary investigation. Academic Medicine. 2006;81:S74-S78.

9. Durning S, Cation LJ, Markert RJ, Pangaro LN. Assessing the reliability and validity of the minievaluation exercise for internal medicine residency training. Acad Med. 2002;77:900-4.

10. Norcini J, Anderson B, Bollela V, Burch V, Costa MJ, Duvivier R, Galbraith R, Hays R, Kent A, Perrott V, Roberts T. Criteria for good assessment: consensus statement and recommendations from the Ottawa 2010 Conference. Med Teach. 2011;33(3):206-14.

11. Tsugawa Y, Tokuda Y, Ohbu S, Okubo T, Cruess R, Cruess S, Ohde S, Okada S, Hayashida N, Fukui T. Professionalism mini-evaluation exercise for medical residents in Japan: a pilot study. Medical Education. 2009;43:968-78.

12. Chandratilake M, Mcaleer S, Gibson J. Cultural similarities and differences in medical professionalism: a multi-region study. Medical Education.2012;46: 257-66.

13. Hodges BD, Ginsburg S, Cruess R, Cruess S, Delport R, Hafferty F, et al. Assessment of professionalism: recommendations from the Ottawa 2010 Conference. Med Teach. 2011;33(5):354-63. 